\title{
Hormones and neoplasia
}

\author{
A. P. M. FORREST \\ From the Department of Surgery, University of Edinburgh
}

My task is to give a broad and general review of the role of hormones in experimental and human neoplasia. Since hormones are concerned with the growth of all tissues, this is possible only if one considers specific hormones and their effect on specific tissues. This review is therefore limited to hormonal influence in cancer of the breast.

\section{A Phenomenon}

A phenomenon, the explanation of which still eludes us, is the regression of human breast cancer which may follow alterations in the hormonal environment. It was first observed in 1895 when recurrent cancer of the breast in a 33-year-old Glasgow woman remitted following removal of the ovaries (Beatson, 1896). The therapeutic advances which followed this observation are well known and include the administration of androgens and oestrogens and removal of the adrenals and the pituitary (Loeser, 1938; Ulrich, 1939; Haddow, Watkinson, and Paterson, 1944; Huggins and Bergenstal, 1952; Luft, Olivecrona, and Sjögren, 1952). The remission rates achieved by these various methods of treatment are remarkably similar; appraximately one third of tumours have a beneficial sponse. Although in most patients the effects are short lived, in some they are prolonged and well nigh dramatic.

\section{Normal Development of the Breast}

It was accepted for many years that only the ovarian hormones, oestrogen and progesterone, were concerned with normal growth of the breast. It is now appreciated that even the simplest form of growth, that of the duct system, cannot be stimulated in the absence of hormones of anterior pituitary origin. The formation of lobules, of alveoli and the production of milk demand even more complex hormonal influences.

As a result of studies in hypophysectomized, oophorectomized, and adrenalectomized rats these are now more clearly defined (Lyons, 1958; Lyons and Dixon, 1966; Cowie and Tindall, 1971). The minimal requirements for ductal growth are now considered to be oestrogen, adrenocortical steroids, and growth hormone. For full lobulo-alveolar development, equivalent to that at the termination of pregnancy, oestrogen, progesterone, prolactin, and growth hormone; and for the initiation of lactation, prolactin, growth hormone, and cortisol. In effect all the hormones shown in fig 1 have a part to play in normal growth of the breast.

Although species differences almost certainly occur it is reasonable to assume that the mechanism of growth control of the human female breast is similar. Small wonder the difficulty in defining the role of hormones on breast neoplasia, particularly as hormones are only one of several factors involved in the initiation and promotion of a tumour.

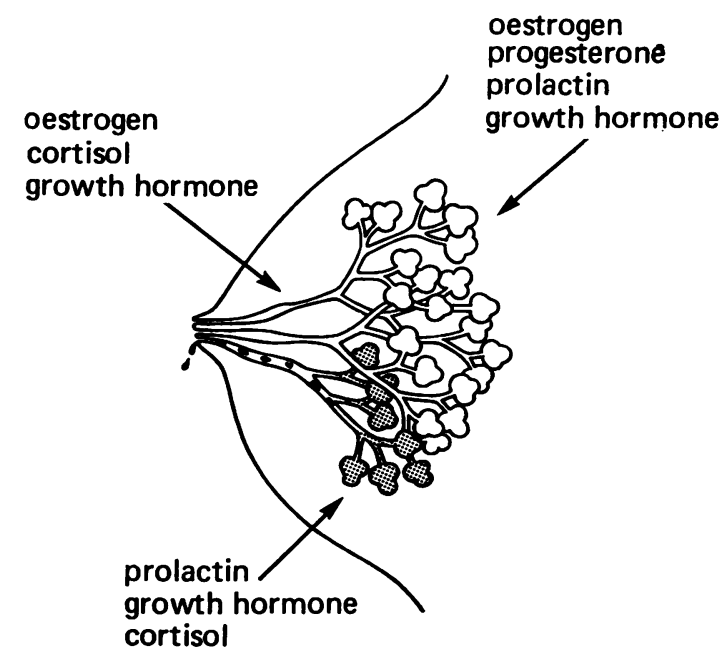

Fig 1 Hormones concerned with normal breast development.

\section{Experimental Tumours}

Since the studies by Mackenzie and Rous (1941) in tar warts, it has been accepted that there are two processes concerned with neoplasia: 'initiation' or the initial neoplastic transformation of a cell and 
'promotion', the provision of conditions necessary for its continued growth and multiplication.

Apparently hormones can form the stimulus necessary for initiation or neoplastic transformation but only when given in unphysiologically large doses (Shimkin, 1958). Their principal effect is to act as promoting agents. Yet there is overlap, for a suitable hormonal environment may still be a necessary prerequisite for tumour induction, irrespective of the stimulus. For example, removal of the source of oestrogens in female rats, before the administration of 7, 12-dimethylbenanthracene (DMBA), prevents tumour induction (Huggins, Briziarelli, and Sutton, 1959). Conversely, intact male rats, normally refractory to the effects of DMBA, develop mammary tumours when provided with functioning ovarian grafts (Dao and Greiner, 1961).

Early observations on spontaneous mammary cancer in mice, ie, that occurring in animals carrying the Bittner milk agent, indicated that the ovarian hormone oestrogen had a promoting role. Removal of the ovaries of female mice reduced its incidence whereas the grafting of functioning ovarian tissue or the administration of oestrogen to male mice, which normally do not develop spontaneous breast cancer, promoted tumour development (Lathrop and Loeb, 1916; Murray, 1928; Lacassagne, 1932). Similar effects have been observed with carcinogeninduced tumours (Bonser, Dossett, and Jull, 1961). There is evidence that the ovarian secretion of progesterone may also promote tumour development and when administered with oestrogen will further enhance its effect (Jull, 1954; Marchant, 1959; Bonser et al, 1961).

Spontaneous mammary cancer in mice may also be influenced by pituitary hormones. The implantation of extra pituitaries, which by virtue of their separation from hypothalamic control secrete prolactin, or the induction of prolactin-secreting tumours of the pituitary by irradiation, increase its incidence (Loeb and Kirtz, 1939; Furth and Clifton, 1958). Conversely hypophysectomy reduces it (Korteweg and Thomas, 1939). Evidence that pituitary hormones are necessary for the promoting effect of oestrogens comes from the observation that hypophysectomy abolishes the high incidence of mammary carcinoma in oestrogen-treated mice, even if oestrogen treatment is continued after the operation (Lacassagne and Chamorro, 1939). Forced breeding and pregnancies may also enhance the development of spontaneous mammary cancer in mice (Bonser et al, 1961).

Recently emphasis has moved from mouse to rat as an experimental model, using the tumour aptly named after Huggins. These mammary tumours can most simply be induced by a single intragastric or intravenous pulse dose of DMBA in fat emulsion administered when the animal is $\mathbf{5 0}$ days of age. In suitable strains of Sprague-Dawley rats adenocarcinomas will develop in the majority of animals in 60 to 100 days. As most of these tumours have the unique property of hormone dependence they are particularly suitable for studies of hormonal effects.

It is firmly established that oestrogens affect the growth of Huggins tumour and some believe that the tumour is primarily oestrogen dependent (Dao, 1962). Removal of ovarian hormones by oophorectomy can induce regression, an effect which is reversible by their administration (Huggins et al, 1959; Sydnor and Cockrell, 1963; Young, Baker, and Helfenstein, 1965). Regression of tumours also follows the administration of testosterone or 5alpha-dihydrotestosterone, this effect also being reversed by oestrogen and progesterone (Huggins $\boldsymbol{e t}$ $a l, 1959$; Young et al, 1965). The demonstration that oestrogen-receptor protein is present in the cells of the tumour and is related to their hormone sensitivity is further evidence that oestrogen is the prime hormone concerned (King, 1968; McGuire and Julian, 1971).

Yet there is now a growing belief that prolactin is equally, if not primarily, implicated. The induction of a high rate of prolactin secretion increases both their incidence and rate of growth (Clemens, Welsch, and Meites, 1968; Pearson, Llerena, Llerena, Molina, and Butler, 1969; Nagasawa and Meites, 1970). As prolactin secretion from the pituitary is controlled by a hypothalamic inhibitory factor, hyperprolactinaemia can readily be achieved by lesions of the median eminence of the hypothalamus, by hypothalamic oestrogen implants, or by the administration of the phenothiazine group of drugs. It has also been shown that the administration of antiprolactin, prepared by immunization, will induce tumour regression (Butler and Pearson, 1972). Recently we have had an opportunity to study three strains of rats in our laboratory which have different incidences of mammary tumour following a single intravenous injection of $5 \mathrm{mg}$ DMBA. Blood was collected during dioestrus from 11 rats in each strain and the concentration of prolactin estimated by radioimmunoassay (Boyns, Buchan, Cole, Forrest, and Griffiths, 1973). This was clearly correlated with tumour incidence (fig 2).

The relationship between prolactin and oestrogen in stimulating tumour growth is further complicated by the finding that oestrogen, in all doses, stimulates prolactin secretion in the rat (Welsch and Meites, 1969). A similar effect occurs in the human female. In recent studies we have shown that both oral and intravenous oestrogen therapy induces hypersecretion of prolactin in women with cancer of the breast 


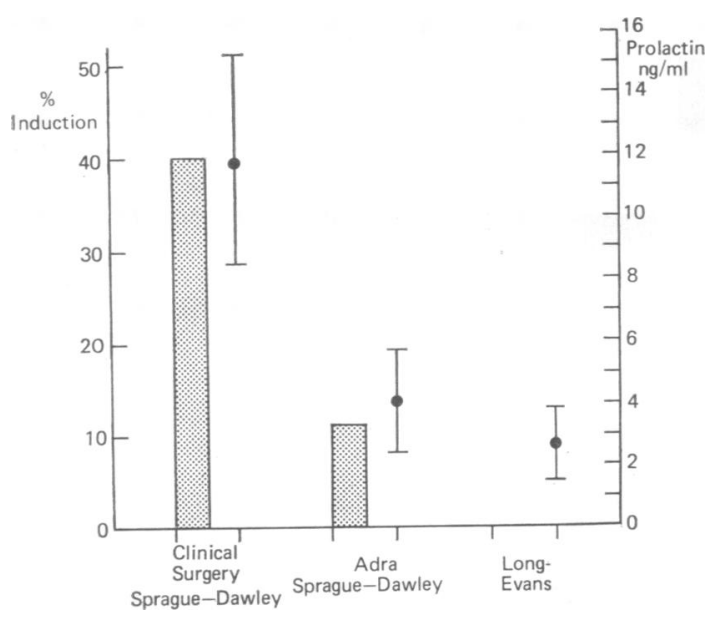

Fig 2 Circulating levels of prolactin and the incidence of mammary cancer induced by 7, 12-dimethyl benzanthracene in three strains of laboratory rats.

(Wilson, Buchan, Roberts, Forrest, Boyns, Cole, and Griffiths, 1973; fig 3).

These various studies with experimental tumours indicate that oestrogen, progesterone, and prolactin are three hormones concerned with the growth of experimental mammary cancer. Doubtless others may also be implicated.

\section{Human Breast Cancer}

Ovarian hormones also influence the behaviour of human breast cancer. The two factors known to

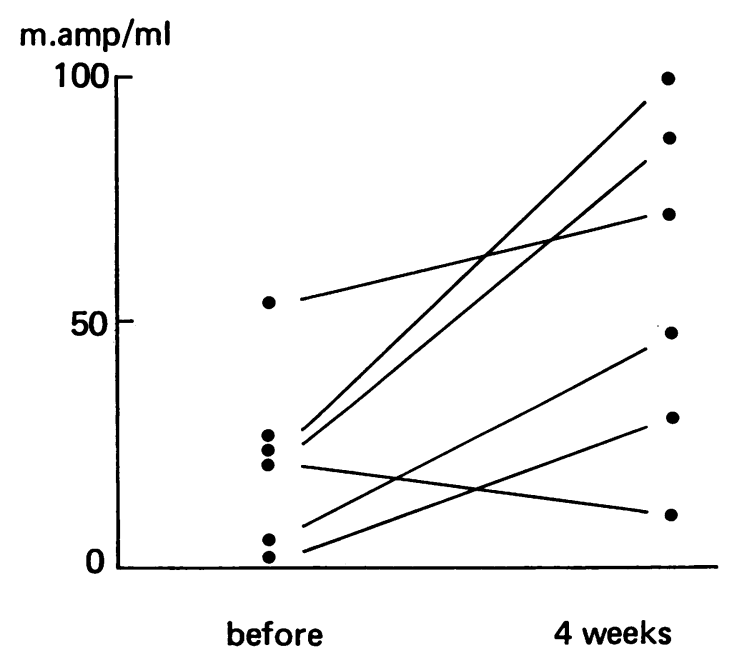

Fig 3 Effect of oral therapy with stilboestrol $5 \mathrm{mg}$ tid on circulating prolactin levels in the human female. exert greatest protection of a woman against the development of cancer of the breast are the age at first pregnancy and the previous performance of an oophorectomy (MacMahon, List, and Eisenberg, 1968; Lowe and MacMahon, 1970; MacMahon et $a l, 1970)$; regression of advanced breast cancer may occur during the natural menopause (Hadfield and Holt, 1956). Conversely enhancement of tumour growth has been observed during the ovarian cycle or as a result of the administration of oestrogen. Increase in the size of soft tissue lesions and of pain and hypercalciuria from bone metastases has been observed during the premenstrual period (Raven, 1950; Kennedy, 1956; fig 4).

Despite these observations, studies of circulating oestrogens have so far proved disappointing. Although the original observation of Huggins and Dao (1953) suggested that the urinary excretion levels of oestrogens, estimated biologically, were correlated with the clinical response to adrenalectomy, this has not been confirmed in subsequent studies using chemical assays (reviewed by Forrest, 1972). Minor differences in the form in which oestrogen is excreted have been noted in women with established breast cancer or who racially are at risk from the disease (Brown, 1958; Marmorston, Crowley, Myers, Stern, and Hopkins, 1965; MacMahon et al, 1971). However, these observations are in part unconfirmed and not necessarily specific to cancer of the breast (Bauld, Givner, and Milne, 1957; Hellman, Fishman, Zumoff, Cassouto, and Gallagher, 1967).

There is also evidence for involvement of the pituitary in human breast cancer. The disease is rare in women with hypopituitarism (Mustacchi and Shimkin, 1957); and enhanced calciuria from bone metastases has been described following the administration of growth hormone and of prolactin (Pearson and Ray, 1959; McCalister et al, 1961).

No clear relationship has so far been observed between circulating hormone levels and the disease. A tendency for women with breast cancer to secrete more growth hormone in response to a glucose load has been described by Greenwood, James, Meggitt, Miller, and Taylor (1968) and Pearson, Llerena, Samaan, and Gonzales (1968), and recently Murray, Mozaffarian, and Pearson (1972) have also reported increased levels of circulating prolactin in this disease. In our experience the growth hormone response to insulin hypoglycemia was normal in women with advanced malignancy of the breast (Stewart, Benson, Roberts, Forrest, and Greenwood, 1971) and circulating prolactin, estimated either by heterologous or homologous immunoassay, has proved to be the same in normal women, women with benign disease of the breast, and those with 


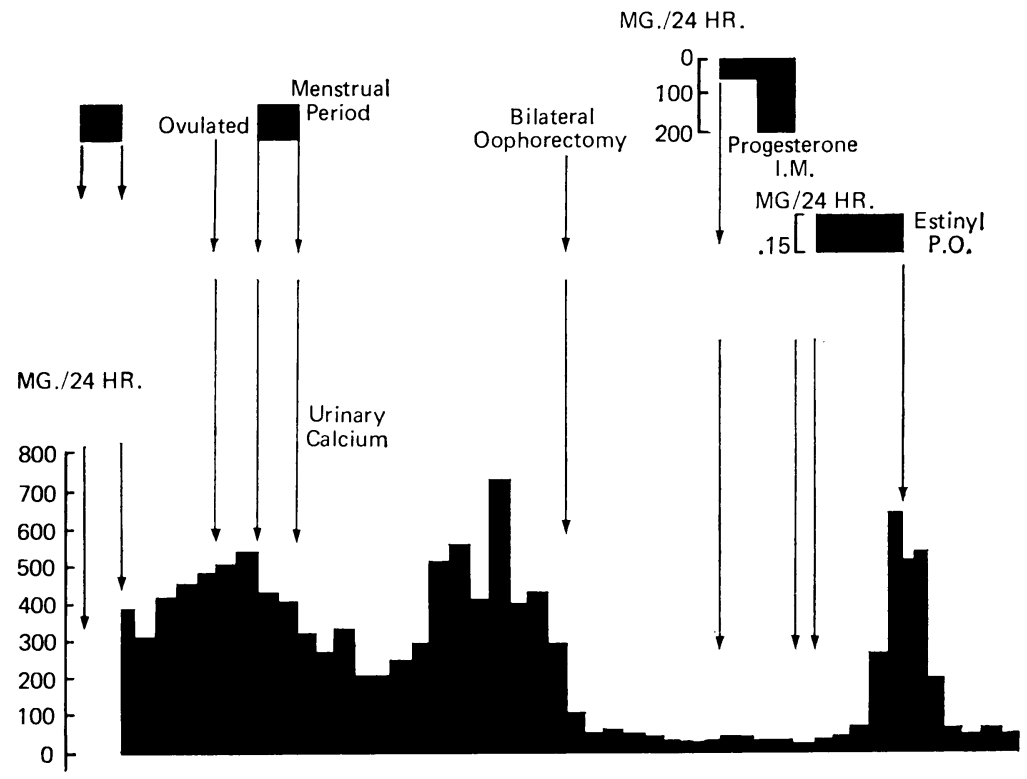

Fig 4 Urinary calcium excretion in patient with bone metastases from mammary cancer to show effect of ovarian cycle, oophorectomy, and oestrogen. (From Pearson et al, 1954.)

cancer (Forrest, 1972; Boyns, Cole, Griffiths, Roberts, Buchan, Wilson, and Forrest, 1973; Wilson et al, 1973). Recent results using a homologous assay are shown in the table. Nor have we found any relationship between the effect of treatment on advanced breast cancer and the levels of circulating plasma prolactin. In fact remission of disease can occur in the face of increased prolactin secretion, even when the surgical procedure is pituitary stalk section (Turkington, Underwood, and Van Wyk, 1971).

Strangely, a stronger relationship has emerged between the levels of the metabolites of the C-19 (androgenic) steroids in the urine and human breast cancer. In a series of papers between 1960 and 1971, Bulbrook and his colleagues have suggested that abnormally low levels of urinary aetiocholanolone may confer an increased risk of breast cancer, a poor prognosis of established disease, and a low incidence of response to endocrine surgery (reviewed by Forrest, 1972). Although these results are not fully confirmed by others, for example, we found abnorm-

\begin{tabular}{llc}
\hline & $\begin{array}{l}\text { Number of } \\
\text { Patients }\end{array}$ & $\begin{array}{l}\text { Prolactin Level } \\
(m A m p / m l\end{array}$ \\
\hline $\begin{array}{l}\text { Control } \\
\text { Primary breast cancer }\end{array}$ & 39 & $8 \cdot 3 \div 1 \cdot 2$ \\
$\begin{array}{l}\text { Advanced } \\
\text { breast cancer }\end{array}$ & 31 & $10 \cdot 9 \div 2 \cdot 2$ \\
\hline
\end{tabular}

Table Circulating prolactin levels in women with cancer of the breast and hospital controls al aetiocholanolone excretion only in women with localized forms of advanced breast cancer (Cameron, Griffiths, Gleave, Stewart, Forrest, and Campbell, 1970), they draw attention to a possible role for steroid hormones other than those of ovarian origin in the disease. Aetiocholanolone is a metabolite of dehydroepiandrosterone and its sulphate secreted by the adrenal cortex. These C-19 steroids are currently of interest in view of the demonstration that human breast cancer and other breast tissues may metabolize them.

\section{The Tumour}

If human breast cancer is incubated or perfused with steroid precursors carrying a radioactive label, conversion to a range of metabolites can be demonstrated (Adams and Wong, 1968; Jones, Cameron, Griffiths, Gleave, and Forrest, 1970; Jenkins and Ash, 1972). By using different substrates one can study different steps in the steroid synthetic pathways and form a pattern such as that shown in figure 5 . While there is some uncertainty regarding the biosynthesis of oestrogens (Adams and Wong, 1972; Dao, Varela, and Morreal, 1972) there is no doubt that circulating DHA-sulphate, the main C-19 steroid secreted by the adrenal, can be converted to the active androgen $5 \alpha$-dihydrotestosterone. Recent observations in our laboratory indicate that similar systems also are present in fibroadenomas of the breast and in normal breast tissues (Miller, 


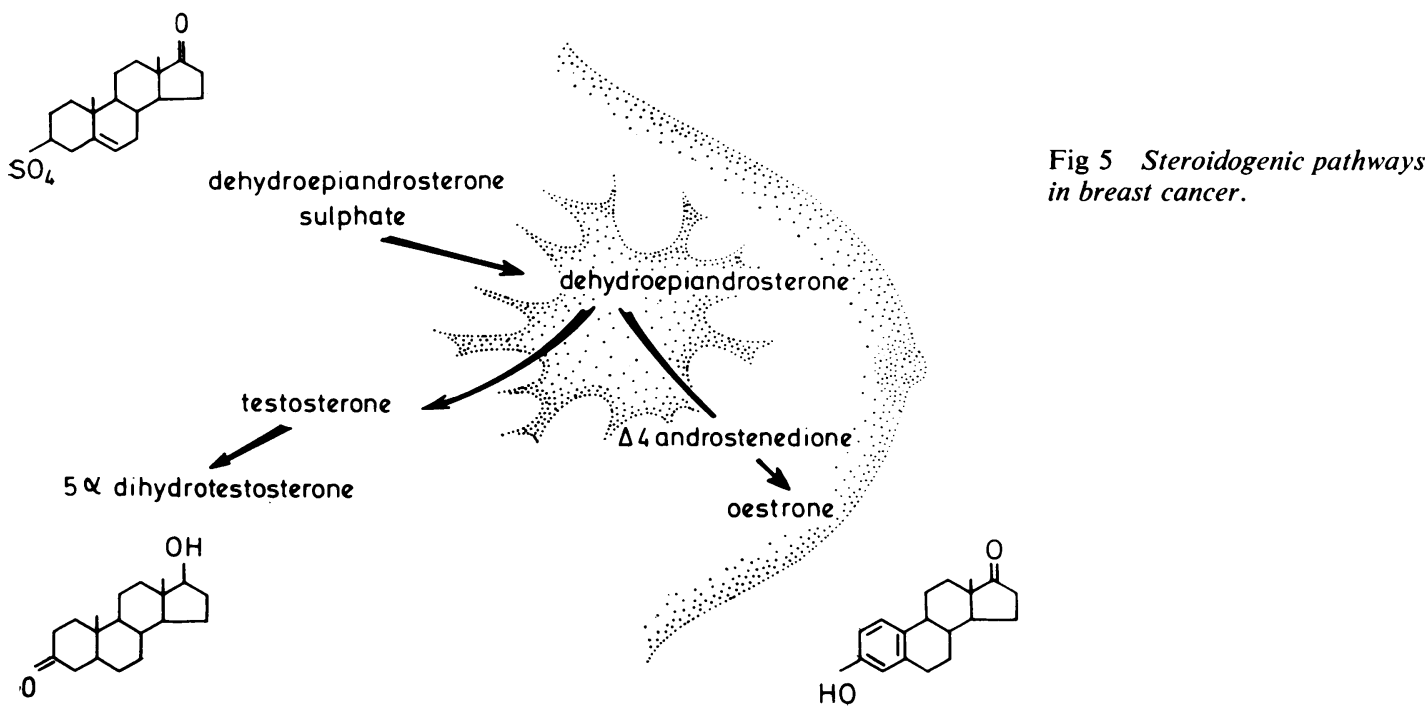

McDonald, Forrest, and Shivas, 1973). In the light of this information absolute levels of circulating hormones may be less important than the ability of the tumour to synthesize growth-promoting steroids which are locally active.

The recent work of Jensen and his colleagues from the Ben May Institute on oestrogen receptor activity has pinpointed another mechanism which may be concerned with the hormonal sensitivity of human breast cancer. Initially defined in the uterus of the immature rat (Jensen and Jacobson, 1960, 1962) it is now clear that high affinity binding protein is also present in the cytoplasm of human breast cancer (Jensen, 1970; Jensen et al, 1972). This cytoplasmic receptor has been identified as an $8 \mathrm{~S}$ protein which is believed to form part of a two-step system responsible for the uptake of oestradiol by the cell and its transport to the nucleus. Of particular importance is the relationship of this oestrogen receptor to hormone dependence; it has been reported by Jensen et al (1972) that only one of 18 human tumours without demonstrable oestrogen receptor activity were responsive to adrenalectomy or hypophysectomy.

A further relationship recently explored is that of sulphating enzymes for oestrogens. These enzymes are responsible for the conjugation of steroid with sulphate and their identification in a tumour has also been related to their hormonal responsiveness (Dao and Libby, 1968, 1972).

It seems obvious that if we hope to unravel the role of hormones on neoplasia, more work is required on the action of hormones on the tumour cell. What other receptor mechanisms are present? Which messenger systems are involved? How do oestrogen and other hormones influence cell growth and multiplication? These are the problems which face investigators in this field and only when they are solved can we hope to explain the phenomenon first described in 1896, yet still ill understood.

References

Adams, J. B., and Wong, M. S. F. (1968). Paraendocrine behaviour of human breast carcinoma; in vitro transformation of steroids to physiologically active hormones. J. Endocr., 41, 41-52.

Adams, J. B., and Wong, M. S. F. (1972). Paraendocrine behavior of human breast cancer. In Estrogen Target Tissues and Neoplasia edited by T. L. Dao, p. 125-150. University of Chicago Press Chicago and London.

Bauld, W. S., Givner, M. L., and Milne, I. G. (1957). Abnormality of estrogen metabolism in human subjects with myocardial infarction. Canad. J. Biochem., 35, 1277-1288.

Beatson, G. T. (1896). On the treatment of inoperable cases of carcinoma of the mamma: suggestions for a new method of treatment, with illustrated cases. Lancet, 2, 104-107 and 162-165.

Bonser, G. M., Dossett, J. A., and Jull, J. W. (1961). Human and Experimental Breast Cancer. Pitman, London.

Boyns, A. R., Buchan, R., Cole, E. N., Forrest, A. P. M., and Griffiths K. (1973). Basal prolactin blood levels in three strains of rat with differing incidence of 7-12 dimethyl/benz(a)anthracene induced mammary tumours. Europ. J. Cancer, 9, 169-172.

Boyns, A. R., Cole, E. N., Griftiths, K., Roberts, M. M., Buchan, R. Wilson, R. G., and Forrest, A. P. M. (1973). Plasma prolactin in breast cancer. Europ. J. Cancer, 9, 99-102.

Brown, J. B. (1958). Urinary oestrogen excretion in the study of, mammary cancer. In Endocrine Aspects of Breast Cancer, edited by A. R. Currie, pp. 197-208. Livingstone, Edinburgh.

Butler, T. P., and Pearson, O. H. (1971). Regression of prolactindependent rat mammary carcinoma in response to antihormone treatment. Cancer Res., 31, 817-820.

Cameron, E. H. D., Griffiths, K., Gleave, E. N., Stewart, H. J., Forrest, A. P. M., and Campbell, H. (1970). Benign and malignant breast disease in South Wales: a study of urinary steroids. Brit. med. J., 4, 768-771.

Clemens, J. A., Welsch, C. W., and Meites, J. (1968). Effects of hypothalamic lesions on incidence and growth of mammary 
tumors in carcinogen-treated rats. Proc. Soc. exp. Biol. (N.Y.), 127, 969-972.

Cowie, A. T., and Tindall, J. S. (1971). The Physiology of Lactation. Arnold, London.

Dao, T. L. (1962). The dual function of hormones in mammary carcinogenesis: a working hypothesis. In On Cancer and Hormones: Essays in Experimental Biology, by A. Haddow et al, pp. 231-242. University of Chicago Press, Chicago.

Dao, T. L., and Greiner, M. J. (1961). Mammary carcinogenesis by 3-methylcholanthrene. III. Induction of mammary carcinoma and milk secretion in male rats bearing ovarian grafts. J. nat. Cancer Inst., 27, 333-349.

Dao, T. L., and Libby, P. R. (1968). Conjugation of steroid hormones by normal and neoplastic tissues. J. clin. Endocr., 28, 14311439.

Dao, T. L., and Libby, P. R. (1972). Steroid sulfate formation in human breast tumors and hormone dependency. In Estrogen Target Tissues and Neoplasia, edited by T. L. Dao, pp. 181200. University of Chicago Press, Chicago and London.

Dao, T. L., Varela, R., and Morreal, C. (1972). Metabolic transformation of steroids by human breast cancer. In Estrogen Target Tissues and Neoplasia, edited by T. L. Dao, pp. 163-179. University of Chicago Press, Chicago and London.

Forrest, A. P. M. (1972). Endocrines and neoplasia of the breast. In Scientific Basis of Surgery, 2nd ed., edited by W. T. Irvine, pp. 635-658. Churchill Livingstone, Edinburgh and London.

Furth, J., and Clifton, K. H. (1958). Experimental observations on mammotropes and the mammary gland. In Endocrine Aspects of Breast Cancer, edited by A. R. Currie, pp. 276-282. Livingstone, Edinburgh and London.

Greenwood, F. C., James, V. H. T., Meggitt, B. F., Miller, J. D., and Taylor, P. H. (1968). Pituitary function in breast cancer. In Prognostic Factors in Breast Cancer: Proceedings of First Tenovus Symposium, 1967, edited by A. P. M. Forrest and B. Kunkler, pp. 409-420. Livingstone, Edinburgh and London.

Haddow, A., Watkinson, J. M., and Paterson, E. (1944). Influence of synthetic oestrogens upon advanced malignant disease. Brit. med. J., 2, 393-398.

Hadfield, G. J., and Holt, J. A. G. (1956). The physiological castration syndrome in breast cancer. Brit. med. J., 2, 972-973.

Hellman, L., Fishman, J., Zumoff, B., Cassouto, J., and Gallagher, T. F. (1967). Studies of estradiol transformation in women with breast cancer. J. clin. Endocr., 27, 1087-1089.

Huggins, C., and Bergenstal, D. M. (1952). Inhibition of human mammary and prostatic cancer by adrenalectomy. Cancer Res., 12, 134-141.

Huggins, C., and Dao, T. L. (1953). Adrenalectomy and oophorectomy in treatment of advanced carcinoma of the breast. J. Amer. med. Ass., 151, 1388-1394.

Huggins, C., Briziarelli, G., and Sutton, H., Jr. (1959). Rapid induction of mammary carcinoma in the rat and the influence of hormones on the tumors. J. exp. Med., 109, 25-42.

Jenkins, J. S., and Ash, S. (1972). Metabolism of testosterone by human breast tumours. Lancet, 2, 513-514.

Jensen, E. V. (1970). The pattern of hormone-receptor interaction. In Some Aspects of the Aetiology and Biochemistry of Prostatic Cancer: Third Tenovus Workshop, edited by K. Griffiths and C. G. Pierrepoint, pp. 151-169. Alpha Omega Alpha, Cardiff.

Jensen, E. V., Block, G. E., Smith, S., Kyser, K., and DeSombre, E. R. (1972). Estrogen receptors and hormone dependency. In Estrogen Target Tissues and Neoplasia, edited by T. L. Dao, pp. 23-57. University of Chicago Press, Chicago and London.

Jensen, E. V., and Jacobson, H. I. (1960). Biological Activities of Steroids in Relation to Cancer, pp. 161-178. Academic Press, New York.

Jensen, E. V., and Jacobson, H. I. (1962). Basic guides to the mechanism of oestrogen action. Recent Progr. Hormone Res., 18, 387-414.

Jones, D., Cameron, E. H. D., Griffiths, K., Gleave, E. N., and Forrest, A. P. M. (1970). Steroid metabolism by human breast tumours Biochem. J., i16, 919-921.

Jull, J. W. (1954). The effects of oestrogens and progesterone on the chemical induction of mammary cancer in mice of the IF. strain. J. Path. Bact., 68, 547-559.

Kennedy, B. J. (1956). Extirpative endocrine therapy for advanced cancer of the breast. Amer. J. Med., 21, 721-727.

King, R. J. B. (1968). An hypothesis on hormone dependence and independence of mammary tumours. In Prognostic Factors in
Breast Cancer; Proceedings of First Tenovus Symposium, 1967, edited by A. P. M. Forrest and P. B. Kunkler, pp. 354-362. Livingstone, Edinburgh and London.

Korteweg, R., and Thomas, F. (1939). Tumor induction and tumor growth in hypophysectomised mice. Amer. J. Cancer, 37 36-44.

Lacassagne, A. (1932). Apparition de cancers de la mammelle chez la souris mâle, soumis à des injections de folliculine. C.R. Acad. Sci., 195, 630-632.

Lacassagne, A., and Chamorro, A. (1939). Conséquences de l'hypophysectomie chez des souris sujettes au carcinome mammaire, traitées par hormone oestrogene. C.R. Soc. Biol. (Paris), 131, 1077-1078.

Lathrop, A. E. C., and Loeb, L. (1916). Further investigations on the origin of tumors in mice. III. On the part played by internal secretion in the spontaneous development of tumors. J. Cancer Res., 1, 1-20.

Loeb, L., and Kirtz, M. M. (1939). The effects of transplants of anterior lobes of the hypophysis on the growth of the mammary gland and on the development of mammary gland carcinoma in various strains of mice. Amer. J. Cancer, 36, 56-82.

Loeser, A. A. (1938). Hormone therapy in mastitis and breast cancer. Brit. med. J., 2, 319.

Lowe, C. R., and MacMahon, B. (1970). Breast cancer and reproductive history of women in South Wales. Lancet, 1, 153-157.

Luft, R., Olivecrona, H., and Sjögren, B. (1952). Hypophysectomy in man (Swedish). Nord. Med., 47, 351-354.

Lyons, W. R. (1958). Hormonal synergism in mammary growth. Proc. roy. Soc. Biol., 149, 303-323.

Lyons, W. R., and Dixon, J. S. (1966). The physiology and chemistry of the mammotrophic hormone. In The Pituitary Gland, edited by G. W. Harris and B. T. Donovan, vol. 1, pp. 527581. Butterworths, London.

McCalister, A., Welbourn, R. B., Edelstyn, G. J. A., Lyons, A. R., Taylor, A. R., Gleadhill, C. A., Gordon, D. S., and Cole, J. O. Y. (1961). Factors influencing response to hypophysectomy for advanced cancer of the breast. Brit. med. J., 1, 613617.

McGuire, W. L., and Julian, J. A. (1971). Comparison of macromolecular binding of estradiol in hormone-dependent and hormone independent rat mammary carcinoma. Cancer Res., 31, 1440-1445.

Mackenzie, I., and Rous, P. (1941). The experimental disclosure of latent neoplastic changes in tarred skin. J. exp. Med., 73, 391415.

MacMahon, B., Cole, P., Brown, J. B., Aoki, K., Lin, T. M., Morgan, R. W., and Woo, N. C. (1971). Oestrogen profiles of Asian and North American women. Lancet, 2, 900-902.

MacMahon, B., Lin, T. M., Lowe, C. R., Mirra, A. P., Ravnihar, B., Salber, E. J., Trichopoulos, D., Valaoras, V. G., and Yuasa, S. (1970). Lactation and cancer of the breast: a summary of an international study. Bull. Wld Hlth Org., 42, 185-194.

MacMahon, B. List N. D., and Eisenberg, H. (1968). Relationship of survival of breast cancer patients to parity and menopausal status. In Prognostic Factors in Breast Cancer: Proceedings of First Tenovus Symposium, 1967, edited by A. P. M. Forrest and P. B. Kunkler, pp. 56-64, Livingstone, Edinburgh and London.

Marchant, J. (1959). Influence of the strain of ovarian grafts on the induction of breast and ovarian tumours in $\mathrm{F}_{1} \mathrm{C}_{57} \mathrm{B1} \times 1 \mathrm{~F}$ hybrid mice by 9:10-dimethyl-1:2-Benzanthracene. Brit. $J$. Cancer, 13, 306-312.

Marmorston, J., Crowley, L. G., Myers, S. M., Stern, E., and Hopkins, C. E. (1965). Urinary excretion of estrone, estradiol and estriol by patients with breast cancer and benign breast disease. Amer. J. Obstet. Gynec., 92, 460-467.

Miller, W. R., McDonald, D., Forrest, A. P. M., and Shivas, A. A. (1973). Metabolism of androgens by human breast tissue. Lancet, 2, 912-913.

Murray, R. M. L., Mozaffarian, G., and Pearson, O. H. (1972). Prolactin levels with L-dopa treatment in metastatic breast carcinoma. In Prolactin and Carcinogenesis: Proceedings of the 4th Tenovus Workshop, edited by A. R. Boyns and K. Griffiths, pp. 158-161. Alpha Omega Alpha, Cardiff.

Murray, W. S. (1928). Ovarian secretion and tumor incidence. J. Cancer Res., 12, 18-25.

Mustacchi, P., and Shimkin, M. B. (1957). Occurrence of cancer in acromegaly and in hypopituitarism. Cancer (Philad.), 10, 100104.

Nagasawa, H., and Meites, J. (1970). Effects of a hypothalamic estro- 
gen implant on growth of carcinogen-induced mammary tumors in rats. Cancer Res., 30, 1327-1329.

Pearson, O. H., Llerena, O., Llerena, L., Molina, A., and Butler, T. (1969). Prolactin-dependent rat mammary cancer: a model for man? Trans. Ass. Amer. Phycns, 82, 225-238.

Pearson, O. H., Llerena, O., Samaan, N., Gonzalez, D. (1968). Serum growth hormone and insulin levels in patients with breast cancer. In Prognostic Factors in Breast Cancer: Proceedings of First Tenovus Symposium, 1967, edited by A. P. M. Forrest and P. B. Kunkler, pp. 421-430. Livingstone, Edinburgh and London.

Pearson, O. H., and Ray, B. S. (1959). A comparison of the results of adrenalectomy and hypophysectomy in carcinoma of the breast. In Cancer, edited by R. W. Raven, vol. 6, pp. 335342. Butterworths, London.

Pearson, O. H., West, C. D., Hollander, V. P. and Treves, N. E. (1954). Evaluation of endocrine therapy for advanced breast cancer. J. Amer. med. Ass., 154, 234-239.

Raven, R. W., (1950). Cancer of the breast treated by oophorectomy. Brit. med. J., 1, 1343-1345.

Shimkin, M. B. (1957). Hormones and neoplasia. In Cancer, edited by $\mathbf{R}$. W. Raven, vol. 1, pp. 161-213. Butterworths, London.

Stewart, H. J., Benson, E. A., Roberts, M. M., Forrest, A. P. M. and Greenwood, F. C. (1971). Pituitary function after yttrium implants as measured by plasma growth hormone levels. $J$. Endocr., 50, 41-50.

Sydnor, K. L. and Cockrell, B. (1963). Influence of estradiol-17 $\beta$ progesterone and hydrocortisone on 3-methylcholanthreneinduced mammary cancer in intact and ovariectomized SpragueDawley rats. Endocrinology, 73, 427-432.

Turkington, R. W., Underwood, L. E., and Van Wyk, J. J. V. (1971). Elevated serum prolactin levels after pituitary stalk section in man. New Engl. J. Med., 285, 707-710.

Uirich, P. (1939). Testostérone (hormone mâle) et son rôle possible dans le traitement de certain cancers du sein. Acta Un. int. Cancr., 4, 377-380.

Welsch, C. W., and Meites, J. (1969). Effects of a norethynodrelmestranol combination (ENOVID) on development and growth of carcinogen induced mammary tumors in female rats. Cancer (Philad.), 23, 601-607.

Wilson, R. G., Buchan, R., Roberts, M. M., Forrest, A. P. M., Boyns, A. R., Cole, E. N., and Griffiths, K. (1973). Prolactin and breast cancer. Proc. roy. Soc. Med., 66, 865-866.

Young, S., Baker, R. A., and Helfenstein, J. E. (1965). The effects of androgen on induced mammary tumours in rats. Brit. $J$. Cancer, 19, 155-159. 